\title{
Research on Blended Learning Practice Based on Student Engagement
}

\author{
Xuyan Sun ${ }^{1}$ and Hui Guan ${ }^{1, *}$ \\ ${ }^{1}$ School of Economics and Management, Dalian University, Dalian, Liaoning 116600, China \\ *Corresponding author. Email: gloria366000@163.com
}

\begin{abstract}
Blended learning has become a mainstream teaching mode in the "Internet + Education" era. Improving student engagement is an effective way to improve the quality of blended learning. To study blended learning practice based on student engagement, we surveyed behavioral engagement, cognitive engagement and emotional engagement. The study found that the overall level of three engagements in blended learning practice is relatively high. However, there are also problems with low cooperative learning among students, weak interaction between students and teachers, and limited ability to expand knowledge. Three suggestions are given to strengthen the blended instructional design, utilize high-quality resources, develop learning platforms, and establish a good learning attitude.
\end{abstract}

Keywords: student engagement; behavioral engagement; cognitive engagement; emotional engagement;

blended learning

\section{INTRODUCTION}

Education Informatization has become one of the important signs of education modernization worldwide. In 2012, the Ministry of Education officially proposed to accelerate the deep integration of information technology and teaching to achieve a revolutionary innovation in educational thinking, concepts and methods. "Ministry of Education's 2019 Work Points" also proposed to accelerate the deep integration of information technology and teaching, and promote the construction of a large platform of "Internet + Education". The deep integration of information technology and teaching means that educators need to fundamentally transform the offline traditional teaching model and use the Internet + information technology to build an "Internet + Education" platform to achieve comprehensive innovation in teaching concepts. Based on this, blended learning, an organic combination of online teaching and offline learning, is bound to be a mainstream teaching mode in the "Internet+" era.

Blended learning is a combination of face-to-face teaching and online learning[1]. Blended learning makes up for the drawbacks of traditional teaching. In this model, teachers comprehensively utilize various teaching resources to impart knowledge and play a guiding and enlightening role; students acquire knowledge according to their needs, mobilizing students' interest and learning motivation. It also strengthens the interaction between teachers and students. It can be seen that blended learning has changed the role of teachers and students in traditional teaching, especially the role of students has been greatly changed. They are no longer passive knowledge recipients, but subjects in the whole process of teaching and learning[2].
Researchers have attempted to study blended learning from the students' perspective. For example, Zhao Tong et al. constructed a blended learning model based on the development of students' core competencies with the mutual support of three factors: teaching environment, resources, and methods[3]. Liang Wei et al. constructed a blended learning ecosystem based on learner satisfaction[4]. However, studying blended learning based on student engagement needs to be further explored.

Student engagement is the time and effort students spend in various learning practice [5]. The extent to which learners are actively engaged in blended learning has a significant impact on their academic performance, educational progress and education quality[6]. Therefore, promoting student engagement is an essential goal of teaching and learning integrated practice[7]. That is, cultivating student engagement is also an important goal of blended learning practice. This article studies student engagement in blended learning practice, explores relevant measures to effectively improve student engagement, and provides a reference for subsequent sustained blended learning practice.

\section{CURRENT STATUS AND PROBLEMS OF STUDENT ENGAGEMENT IN BLENDED LEARNING PRACTICE}

More and more educators are engaged in blended learning practice, expecting this "new normal" to change traditional teaching. It considers students as the main body, prompts teachers to invest more in "teaching" and students to invest in "learning" more effectively, and enhances student engagement. It will become an effective model for improving education and teaching quality. 
Student engagement is a multidimensional structure. Based on Fredricks' three-dimensionality theory and the content of interviewers, we conclude that student engagement includes behavioral engagement, cognitive engagement and emotional engagement. The details are shown in Table 1. We surveyed the blended learning practice of Marketing course at Dalian University. Eighty-eight valid questionnaires were returned to analyze the engagement of the 19-year undergraduates.

From the overall analysis of the data, $13.81 \%$ of students had the highest level of student engagement, $48.99 \%$ had a high level, $20.91 \%$ had a medium level, $11.48 \%$ had a low level, and $4.81 \%$ had the lowest level.

Students' cognitive engagement was the highest overall at $64.78 \%$, behavioral engagement at $62.81 \%$, and emotional engagement at $60.80 \%$.

Overall, more than half of the students had a good engagement status, promoting the blended learning practice. It also shows that blended learning can improve student engagement to some extent. And it can enhance students' sense of subjective learning and active participation in learning. However, there are still problems in some aspects and the quality of blended learning needs to be enhanced.

\subsection{Low Cooperative Learning among Students}

Hardworking and focused reflects the effort and focus students put into the learning process, and it is an important indicator to measure students' behavioral engagement. The survey results show that $73.86 \%$ and $73.85 \%$ of students would overcome the difficulties in the learning process and maintain their attention, and $65.91 \%$ would complete their learning tasks on time, indicating a high level of effort and concentration in the course teaching process. But in terms of cooperative learning, $15.91 \%$ of students did not regard classmates as learning partners, and $14.77 \%$ hardly sought help from classmates when they encountered difficulties. This reflects that although students can complete the learning tasks, they are less engaged in cooperative learning. Therefore, how to enhance cooperative learning among students is one of the issues that teachers should pay attention to when designing blended learning courses.

\subsection{Weak Interaction between Students and Teachers}

Whether in traditional teaching or blended learning, teachers play a very important role. However, teachers tend to invest more in the course teaching, and less in the relationship between teachers and students. The survey results show that although $15.91 \%$ of students sought help from teachers when they encountered learning difficulties, $3.41 \%$ did not seek help from teachers at all, and $15.91 \%$ hardly considered teachers as learning partners and did not actively obtain learning resources from teachers. Besides, $32.95 \%$ of students reported that they did not receive answers from teachers when they encountered difficulties, which is likely to lead to students' reluctance to communicate with teachers. Nearly half of the students had positive attitudes toward blended learning enhancing student-teacher interaction, but nearly $30 \%$ had negative attitudes. This is a common problem in blended learning practice.

The interaction between teachers and students helps strengthen the connection between them, helping teachers to teach more efficiently and students to learn more effectively. In addition, they can use various resources online and offline to interact. In this process, teachers still play a guiding role to enhance the level of teacher-student interaction.

Table 1. Student Engagement Indicators

\begin{tabular}{|c|c|c|}
\hline \multicolumn{2}{|c|}{ Indicators } & Details \\
\hline \multirow{3}{*}{$\begin{array}{c}\text { Behavioral } \\
\text { Engagement }\end{array}$} & $\begin{array}{c}\text { Active } \\
\text { Learning }\end{array}$ & $\begin{array}{l}\text { Actively seek } \\
\text { learning resources; } \\
\text { Summarize the } \\
\text { knowledge learned }\end{array}$ \\
\hline & $\begin{array}{l}\text { Hardworking } \\
\text { and focused }\end{array}$ & $\begin{array}{l}\text { Overcome difficulties; } \\
\text { Complete learning } \\
\text { tasks on time; } \\
\text { Maintain } \\
\text { concentration }\end{array}$ \\
\hline & $\begin{array}{l}\text { Teacher- } \\
\text { student } \\
\text { interaction }\end{array}$ & $\begin{array}{l}\text { Treat teachers and } \\
\text { classmates as study } \\
\text { partners; Turn to them } \\
\text { for help and answers } \\
\text { when encountering } \\
\text { problems }\end{array}$ \\
\hline \multirow{3}{*}{$\begin{array}{c}\text { Cognitive } \\
\text { Engagement }\end{array}$} & $\begin{array}{c}\text { Process } \\
\text { Management }\end{array}$ & $\begin{array}{l}\text { Arrange study time } \\
\text { reasonably; Have } \\
\text { study plan and goals }\end{array}$ \\
\hline & $\begin{array}{c}\text { Mastery } \\
\text { consolidation }\end{array}$ & $\begin{array}{l}\text { Master the knowledge } \\
\text { learned; Consolidate } \\
\text { the knowledge } \\
\text { structure }\end{array}$ \\
\hline & $\begin{array}{l}\text { Knowledge } \\
\text { Expansion }\end{array}$ & $\begin{array}{l}\text { Apply the knowledge } \\
\text { learned to practical } \\
\text { problem solving }\end{array}$ \\
\hline \multirow[b]{3}{*}{$\begin{array}{c}\text { Emotional } \\
\text { Engagement }\end{array}$} & Love & Love blended learning \\
\hline & Burnout & $\begin{array}{l}\text { Affected by peers' } \\
\text { burnout on blended } \\
\text { learning }\end{array}$ \\
\hline & Identify with & $\begin{array}{l}\text { Can quickly adapt to } \\
\text { blended learning; } \\
\text { Blended learning is } \\
\text { conducive to } \\
\text { motivating learning, } \\
\text { can improve learning } \\
\text { efficiency, and can } \\
\text { bring a sense of } \\
\text { accomplishment }\end{array}$ \\
\hline
\end{tabular}




\subsection{Limited Ability to Expand Knowledge}

Most students can organize their time, plan their learning and master what they have learned. But their ability to apply what they have learned to practical problem solving still needs to be improved. The survey results show that nearly $70 \%$ of students can find their learning methods to master what they have learned, but $11.36 \%$ are still unable to combine what they have learned with reality and apply it. So improving students' ability to expand their knowledge is a difficult part of the blended learning parctice. Students pay more attention to the mastery of knowledge, which may have much to do with teachers' daily use of course resources, causing students to neglect the improvement of knowledge expansion ability.

\subsection{Slightly Less Emotional Engagement}

The extent to students' recognition of blended learning plays an important role in carrying out practices. The more students agree and accept the blended teaching model, the easier it is for teachers to carry out their work. The survey results show that over $60 \%$ of students had feelings of liking and agreeing with the blended learning model. Most students can adapt to blended learning quickly. And they believe that blended learning is conducive to motivating learning, improving learning efficiency, and gaining a sense of accomplishment. So they are more willing to engage in a blended learning environment. Students have a higher acceptance of blended learning and interest in it. However, $45 \%$ of students are affected by their peers' burnout on blended learning. This also reflects that blended learning practice should be carried out in a way that reasonably stimulates students' positive emotions and prevents the interplay of negative emotions among students.

\section{SUGGESTIONS FOR IMPROVING BLENDED LEARNING PRACTICE}

\subsection{Strengthen the Blended Instructional Design to Enhance Collaboration and Student- Teacher Interaction}

Blended learning reform is still in the exploration stage, and teachers are not very familiar with blended instructional design. This is one of the reasons for low cooperation among students and weak teacher-student interaction. Good teaching cannot be achieved without a well-prepared instructional design by the teacher, and instructional design is a major factor influencing student engagement. The improvement of teachers' instructional design and classroom organization skills has an important impact on student engagement and teaching quality[8]. The blended instructional design should run through the entire process of teaching and learning, including not only the three-stage design before, during and after class but also the design of how online and offline teaching cooperates. The design is shown in Figure 1. Teachers need to integrate pre-class, in-class, post-class teaching, and online and offline teaching to effectively carry out blended learning reform.

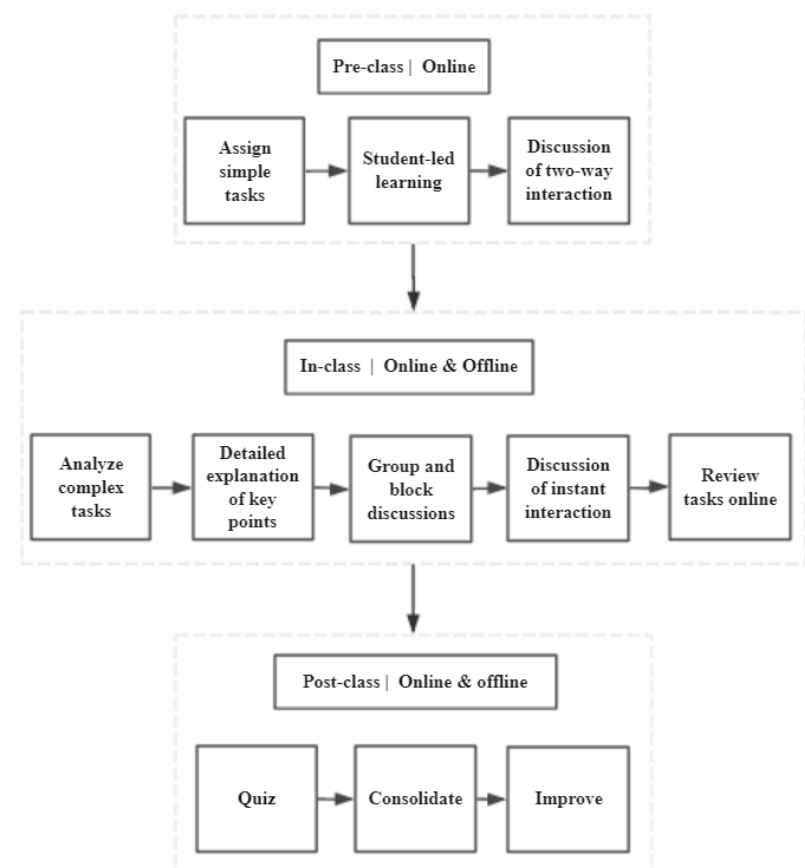

Figure 1. Blended Instructional Design Process

\subsubsection{Pre-class stage, two-way interaction between teachers and students online}

At the pre-class stage, teachers publish relatively simple knowledge understanding tasks on the online platform and provide resources for students to learn independently. Students can complete them at their own suitable time. At the same time, students are required to leave their learning experience and any knowledge points they do not understand in the online platform discussion area, then the teacher will answer questions through live streaming to achieve two-way interaction between teachers and students online. It is also possible to add teaching assistants to assist with online Q\&A.

\subsubsection{In-class stage, instant interaction between teachers and students online and offline}

At the in-class stage, teachers mainly focus on complex learning tasks. At this time, teachers and students 
communicate face-to-face offline for instant interaction, so that students can better understand and absorb what they have learned. Teachers need to disassemble the complex knowledge points, explain the important and difficult parts in detail, and discuss them in groups according to the learning effectiveness of different students. After discussion among the students, the teacher will make supplements and repeat this cycle until the students understand it. And then the learning resources are available online for students to review the knowledge points.

\subsubsection{Post-class stage, effective interaction between teachers and students online and offline}

At the post-class stage, teachers mainly conduct tests to assess knowledge points and consolidate students' mastery of what they have learned. Text-based assessments are carried out online, and operational assessments are offline, achieving effective interaction between teachers and students. Finally, teachers and students discuss the advantages and disadvantages of the teaching design, summarize teaching experience, and carry out the next teaching plan.

\subsection{Utilize High-Quality Resources and Develop Learning Platforms to Enhance Knowledge Expansion Capabilities}

Colleges and universities should promote blended learning exploration practice to provide backing for blended learning and holistically enhance student engagement. Firstly, adjust the training program and talent training objectives, pay attention to the development of students' higher-order thinking, and cultivate talents suitable for the information technology era. Secondly, provide teachers with a suitable environment, technology resources and technology training for blended learning using high-quality resources. Finally, increase the construction of hardware facilities, optimize the teaching management system, and reasonably use or develop learning platforms to provide students with sufficient resources.

Teachers should scientifically and effectively carry out blended learning practice, select suitable teaching methods based on the characteristics and requirements of each major and course, and reasonably utilize the high-quality teaching resources on the open platform. They also should actively participate in technical training to master the technical means. Finally, they use the learning platform to help students enhance their vision and use teaching conditions to enhance students' knowledge expansion capabilities.

Students should cooperate with teachers in the blended learning reform. Both sides should have mutual contact and close teacher-student interaction. This is also the focus of blended learning. In blended learning, teachers will gradually guide students. At this time, students should set the right attitude. First, follow the teacher's guidance to complete tasks, communicate and discuss on the learning platform. Second, acquire new knowledge, process new knowledge and gradually enter the realm of deep learning in a good learning atmosphere. Third, cultivate high-level thinking and gradually enhance the ability to apply what they have learned and creatively solve practical problems.

\subsection{Establish a Good Learning Attitude to Improve Emotional Engagement}

Studies have shown that students hold positive attitudes toward blended learning reform[9]. Students' positive attitudes toward blended learning reform affect their engagement in blended learning practice[10]. Therefore, students should establish a good learning attitude in the blended learning reform, try to overcome negative emotions, enhance their interest in blended learning, and improve their overall emotional engagement in blended learning. This is not only a responsible attitude towards learning but also a quick way to adapt to the blended learning.

\section{CONCLUSION}

Blended learning is the mainstream teaching model in the "Internet +" era, promoting global education and teaching reforms. Developments in today's educational field emphasize cultivating learners' creative thinking, critical thinking, and interpersonal and collaborative skills. These also require learners to be deeply engaged to achieve their learning goals.

The results of this paper indicate that the overall level of student engagement in blended learning practice is relatively high, with behavioral engagement, cognitive engagement and emotional engagement reaching more than $60 \%$; The student engagement perspective contributes to the study of blended learning practice, and the quality of blended learning can be improved through student engagement. Colleges and universities actively promote blended learning reform, encourage teachers to carry out blended learning practice, and provide high-quality resources; teachers work scientifically in line with talent training objectives, design and improve effective teaching process, strengthen interaction with students, and allow students to benefit from blended learning; stimulate students' positive emotions towards blended learning and enhance their sense of identity; students must improve their knowledge and innovation level to meet the requirements of the new era.

\section{REFERENCES}

[1] L. R. Halverson, and C. R. Graham, "Learner engagement in blended learning environments: A conceptual framework," Online Learning. Newburyport, vol. 23, pp. 145-178, June 2019. DOI: https://doi.org/10.24059/olj.v23i2.1481 
[2] F. Martin, C. Wang, and A. Sadaf, "Student perception of helpfulness of facilitation strategies that enhance instructor presence, connectedness, engagement and learning in online courses," The Internet and Higher Education. New York, vol. 37, pp.52-65, April 2018. DOI:

https://doi.org/10.1016/j.iheduc.2018.01.003

[3] T. Zhao, F. C. Zhao, and Y. J. Huang, "Research on Blended Teaching Mode and Implementation Path Based on the Development of Students' Core Competencies - Taking the Teaching of College Tourism as an Example," China Educational Technology. Beijing, vol. 389, pp. 95-101, June 2019. (In Chinese)

[4] W. Liang, H. M. Zhang, H. Chen and J. X. Dai, "Research on Blended Teaching based on Learners' Satisfaction Degree," Modern Educational Technology. Beijing, vol. 30, pp. 112-118, October 2020. DOI: https://doi.org/10.3969/j.issn.1009-8097.2020.010.016 (In Chinese)

[5] J. A. Fredricks, "School Engagement: Potential of the Concept, State of the Evidence," Review of Educational Research. Thousand Oaks, vol. 74, pp. 59109, spr 2004. DOI: https://doi.org/10.3102/00346543074001059

[6] G. D. Kuh, "What We're Learning About Student Engagement From NSSE: Benchmarks for Effective Educational Practices," Change: The Magazine of
Higher Learning. The United States, vol. 35, pp. 24-32, March 2003. DOI:

https://doi.org/10.1080/00091380309604090

[7] S. Ellen, F. Carrie, M. Gwen, and K. Thomas, "Engagement and disaffection in the classroom: Part of a larger motivational dynamic," Journal of Educational Psychology. Washington, vol. 100, pp. 765-781, November 2008. DOI: https://doi.org/10.1037/A0012840

[8] S. K. D’Mello, and A. Graesser, "AutoTutor and Affective AutoTutor: Learning by talking with cognitively and emotionally intelligent computers that talk back," ACM Transactions on Interactive Intelligent Systems. The United States, vol. 2, pp. 1-39, January 2013. DOI: https://doi.org/10.1145/2395123.2395128

[9] M. C. S. Gómez, F. J. García-Peñalvo, and A. M. P. Llorente, "Assessing the Effectiveness of Interactive and Collaborative Resources to Improve Reading and Writing in English," International Journal of Human Capital and Information Technology Professionals (IJHCITP). Hershey, vol. 7, pp. 66-85, January 2016. DOI: https://doi.org/10.4018/IJHCITP.2016010105

[10] D. Holley, and C. Dobson, "Encouraging student engagement in a blended learning environment: the use of contemporary learning spaces," Learning, Media and Technology. The United Kingdom, vol. 33, pp. 139150, June 2008. DOI: https://doi.org/10.1080/17439880802097683 